\title{
Changes in Polish Tourist Flows TO THE Eastern Adriatic
}

\author{
Jan A. WENDT, Gdańsk*
}

with 1 figure and 6 tables in the text

\section{Content}

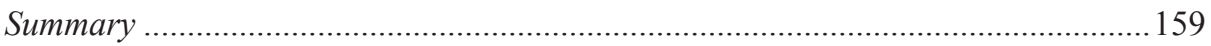

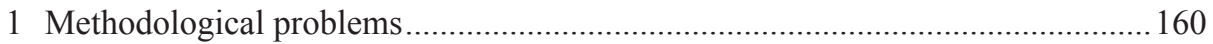

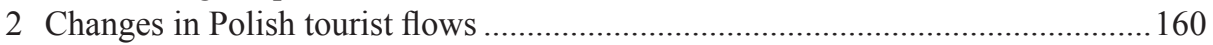

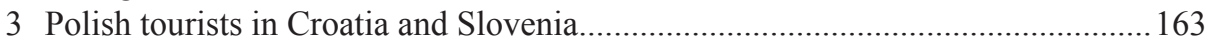

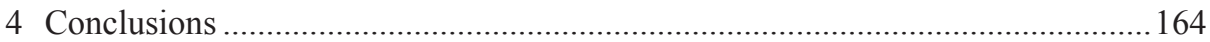

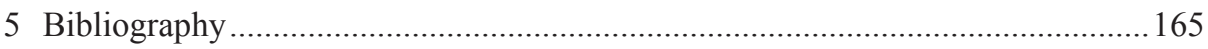

\section{Summary}

The paper aims at an analysis of changes in Polish tourist flows to the eastern coasts of the Adriatic after 1989, especially to Slovenia and Croatia. The analysis focuses on economic factors of tourism development as well as on factors of touristic attractiveness of these countries for Polish tourists such as cultural affinity, low prices and good accessibility.

\footnotetext{
Jan WENDT, Prof. dr. hab., Department of Regional Development Geography, Gdańsk University, ul. Bażyńskiego 4, PL 80-952 Gdańsk, and Department of Tourism Economics, Academy of Physical Education and Sport, ul. Kazimierza Górskiego 1, PL 80-336 Gdańsk; e-mail: jan.wendt@ug.edu.pl
} 


\section{Methodological problems}

The Adriatic region is besides Greece and Spain one of the most important tourist destinations in Europe. After 1989 this region has also become one of the most popular destinations for Polish tourists. It may therefore be interesting to identify the factors that cause the flow of Polish tourists to the Adriatic coast and to determine the changes since 1989.

As regards the concept of tourism we depart from the definition presented by the World Tourism Organization (WTO) saying that tourism includes all activities of people who travel for leisure, business or other purposes for no longer than a year without a break outside their everyday environment. So we define a tourist as a person, who resides in a place outside his/her home at least for one day or spends at least one night in a tourist accommodation. Persons staying less than a day are classified as excursionists.

A major problem in the context of this study is availability and reliability of data describing size and spatial spread of tourist traffic. Differences in statistical methods of national statistical agencies in Croatia and Slovenia let us prefer to use data published by the Central Statistical Office of Poland, since they are homogenous, collected and elaborated on the basis of a consistent methodological framework.

It has also to be mentioned that the owners of accommodation facilities are not so much interested in delivering reliable data, mainly for tax reasons. Furthermore, data on day trips and excursions are practically not available, although these forms of tourism play a major role with Polish tourists. Therefore, we use in addition to data provided by the Central Statistical Office of Poland a survey conducted by the Tourist Institute in Warsaw [Warszawa] (2010). For practical reasons, the study is confined to Croatia and Slovenia.

\section{Changes in Polish tourist flows}

After the political turn of 1989/90 economic transformation and economic reforms had strengthened the purchasing power of the Polish currency and the Złoty has become fully convertible. This made it possible for Poles to travel also under the conditions of commercial tourism, not only - as in Communist times - of Socialist welfare tourism. Thus, the years 1991-2000 saw an increase of Polish trips to abroad from about 20 to 56.7 millions. A weakening of the economy and a decrease of the real value of the Polish Złoty in 2003-2004 caused a decline up to 2004, when the number of Polish trips to abroad fell to the level of 37.2 millions (see Figure 1). Later, the Polish accession to the European Union (EU) and the Schengen Space resulted again in an increase of Polish trips to abroad. 
Figure 1: Polish trips to abroad including day trips 1991-2007 (in millions)

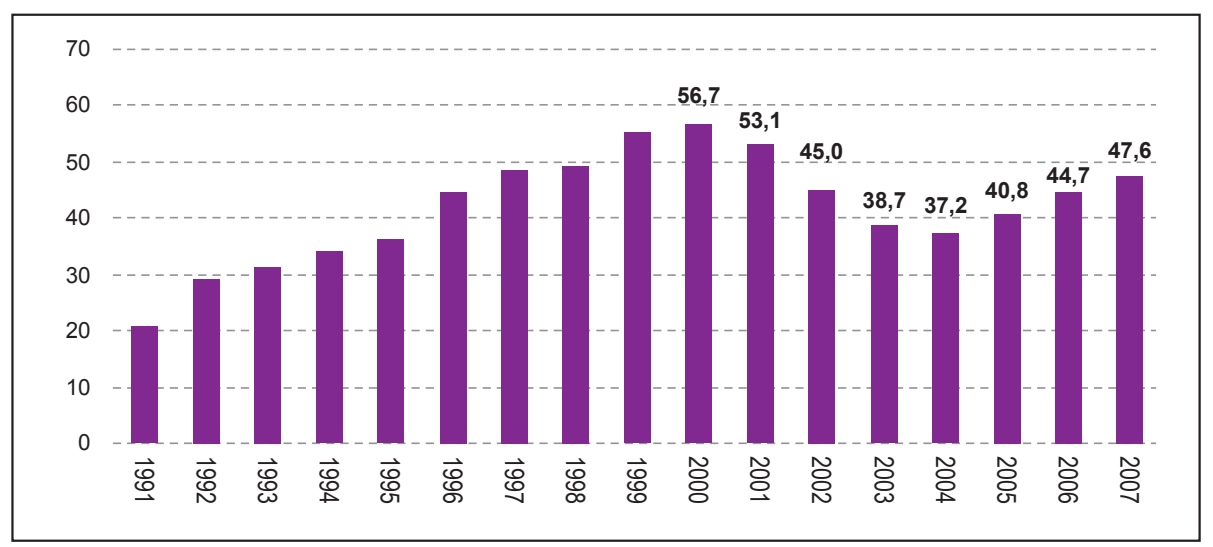

Source: Tourist Institute 2010, Warsaw

Also in terms of Polish tourists to abroad (in the sense of persons spending at least one night in a tourist accommodation abroad), the years 2000-2009 saw a significant decrease from 9.6 to 6.3 millions (see Table 1).

The most popular destination of Polish tourists is - not surprising, given the size of Polish religious and pilgrimage tourism - Italy with about 650,000 tourists in 2009 . In the same year Croatia was visited by about 300,000 and Slovenia by only 30,000 Polish tourists. Besides Italy and Croatia also Egypt, Spain and France are popular tourist destinations of Poles in the Mediterranean. France, however, is not so much visited for its Mediterranean coast, but for urban attractions like Paris.

Compared to the overall decrease between 2000 and 2009, Egypt and Croatia stand out as winner destinations (see Table 1). From 2004 to 2009 the number of Polish tourists in Egypt has increased from 100,000 to 250,000 and in Croatia from 150,000 to 300,000 . This is mainly due to economic factors like value for money, but also to the recreational values of the two countries. In contrast, Polish tourism to Spain and Greece declined or stagnated. During the same period the number of Polish tourists in Greece remained at the level of 150,000; in Spain it increased from 150,000 to 250,000, but did not return to the level of 2000, when Spain was visited by about 400,000 Polish tourists. 
Table 1: Polish tourists in selected Mediterranean countries (millions)

\begin{tabular}{|l|r|r|r|r|r|r|r|r|r|r|}
\hline $\begin{array}{c}\text { Year/ } \\
\text { Country }\end{array}$ & 2000 & 2001 & 2002 & 2003 & 2004 & 2005 & 2006 & 2007 & 2008 & 2009 \\
\hline Croatia & 0.40 & 0.50 & 0.30 & 0.20 & 0.15 & 0.25 & 0.25 & 0.25 & 0.30 & 0.30 \\
\hline Egypt &. &. &. & 0.10 & 0.10 & 0.10 & 0.15 & 0.15 & 0.25 & 0.25 \\
\hline France & 0.75 & 0.50 & 0.55 & 0.35 & 0.20 & 0.30 & 0.20 & 0.45 & 0.35 & 0.20 \\
\hline Greece & 0.50 & 0.25 & 0.55 & 0.15 & 0.15 & 0.15 & 0.10 & 0.15 & 0.30 & 0.15 \\
\hline Italy & 1.00 & 0.60 & 0.45 & 0.55 & 0.50 & 0.55 & 0.45 & 0.35 & 0.45 & 0.65 \\
\hline Slovenia &. &. &. & 0.02 & 0.02 & 0.02 & 0.02 & 0.03 & 0.03 & 0.03 \\
\hline Spain & 0.40 & 0.30 & 0.30 & 0.15 & 0.15 & 0.15 & 0.10 & 0.30 & 0.30 & 0.25 \\
\hline Turkey &. &. & 0.10 &. &. & 0.10 & 0.10 & 0.10 & 0.15 & 0.15 \\
\hline Total & $\mathbf{9 . 6 0}$ & $\mathbf{7 . 7 0}$ & $\mathbf{8 . 4 0}$ & $\mathbf{7 . 2 0}$ & $\mathbf{6 . 3 0}$ & $\mathbf{6 . 2 0}$ & $\mathbf{7 . 3 0}$ & $\mathbf{6 . 9 0}$ & $\mathbf{7 . 6 0}$ & $\mathbf{6 . 3 0}$ \\
\hline
\end{tabular}

Source: Tourist Institute 2010, Warsaw

Poles prefer travelling individually. In the years $2004-2009$ only about $15-20 \%$ of all trips were organized by travel agencies. About $10 \%$ were business trips, while 59$65 \%$ were organized individually. Among the trips undertaken individually, Croatia and Slovenia rank prominently as destinations. They can be reached by private car in about 18-20 hours from southern Poland. The distance between Gdańsk in northern Poland and Dubrovnik is about 1,900 km, between Wrocław in southwestern Poland and Split $1,200 \mathrm{~km}$. This is feasible in two days with one overnight stay at the maximum.

Table 2: Polish foreign tourism by purpose (\%)

\begin{tabular}{|l|r|r|r|r|r|r|r|r|}
\hline Categories & $\mathbf{2 0 0 2}$ & $\mathbf{2 0 0 3}$ & $\mathbf{2 0 0 4}$ & $\mathbf{2 0 0 5}$ & $\mathbf{2 0 0 6}$ & $\mathbf{2 0 0 7}$ & $\mathbf{2 0 0 8}$ & \multicolumn{1}{c|}{2009} \\
\hline Tourism & 44 & 48 & 38 & 47 & 44 & 42 & 52 & 52 \\
\hline Family visit & 28 & 23 & 22 & 26 & 23 & 25 & 25 & 22 \\
\hline Professional & 17 & 23 & 33 & 19 & 19 & 26 & 18 & 17 \\
\hline Others & 11 & 6 & 7 & 8 & 14 & 7 & 5 & 9 \\
\hline
\end{tabular}

Source: Tourist Institute 2010, Warsaw

As regards travel purposes, classic tourism ranks first rising from $44 \%$ in 2002 to $52 \%$ in 2009 (see Table 2). The second place hold visits to family members and friends, the third business trips. Both have either declined or not grown since 2002 due to the weakening of the economy in Poland.

Table 3 shows expenditures of Polish tourists travelling abroad, perhaps the most important criterion from the destination's point of view. 
Table 3: Travel of Polish tourists to abroad (in Euro)

\begin{tabular}{|c|c|c|c|c|c|c|c|c|}
\hline & 2002 & 2003 & 2004 & 2005 & 2006 & 2007 & 2008 & 2009 \\
\hline \multicolumn{9}{|c|}{ Travel expenses } \\
\hline during travel & 166 & 163 & 201 & 197 & 224 & 239 & 333 & 330 \\
\hline before travel & 171 & 140 & 176 & 167 & 239 & 238 & 346 & 342 \\
\hline \multicolumn{9}{|c|}{ Daily cost of travel } \\
\hline during travel & 15 & 14 & 15 & 14 & 15 & 15 & 22 & 20 \\
\hline before travel & 15 & 12 & 13 & 13 & 15 & 15 & 23 & 27 \\
\hline
\end{tabular}

Source: Tourist Institute 2010, Warsaw

As Table 3 shows, expenditures almost doubled from 2002 to 2009. The increase was especially significant from 2005 to 2009, when the purchasing power of the Złoty and the Polish economy grew. The growth of daily expenses, however, was much smaller. This can be explained by two reasons. The first is the growth of purchasing power of the Polish Złoty from 2002 to 2009, which improved its exchange rate with the Euro from 5.5 to 3.9 to 1 . In 2009 (February) for 1 Euro only 3.1 Złoty had to be paid. A second reason are longer holidays with more overnight stays.

\section{Polish tourists in Croatia and Slovenia}

Factors most relevant for Polish tourism to the Adriatic region are tourist attractions, economic factors and safety. In terms of tourist attractions, both Croatia and Slovenia dispose over a wealth of natural as well as cultural assets. This is reflected by the overall number of foreign tourists in these two countries, which is impressive and significantly growing especially in Croatia (see Table 4).

Table 4: Foreign tourists in Croatia and Slovenia 2004-2008 (in 1,000)

\begin{tabular}{|l|r|r|r|r|r|}
\hline & \multicolumn{1}{|c|}{$\mathbf{2 0 0 4}$} & \multicolumn{1}{c|}{$\mathbf{2 0 0 5}$} & \multicolumn{1}{c|}{$\mathbf{2 0 0 6}$} & \multicolumn{1}{c|}{$\mathbf{2 0 0 7}$} & \multicolumn{1}{c|}{$\mathbf{2 0 0 8}$} \\
\hline Croatia & 9,412 & 9,995 & 10,385 & 11,162 & 11,261 \\
\hline Slovenia & 1,499 & 1,555 & 1,617 & 1,751 & 1,771 \\
\hline
\end{tabular}

Source: Tourist Institute 2010, Warsaw

Besides natural and cultural attractions as well as safety and security, major reasons for Poles to go for vacations to Croatia and Slovenia are cultural similarities with Poland 
such as a similar course of transformation, related languages or the common Roman Catholic denomination. Also similar features in history like having been occupied by neighbouring countries create an atmosphere of mutual understanding.

Table 5: Polish tourists in Croatia and Slovenia 2003-2009 (in 1,000)

\begin{tabular}{|l|r|r|r|r|r|r|r|}
\hline & \multicolumn{1}{|c|}{$\mathbf{2 0 0 3}$} & \multicolumn{1}{c|}{2004} & \multicolumn{1}{c|}{2005} & \multicolumn{1}{c|}{2006} & \multicolumn{1}{c|}{2007} & \multicolumn{1}{c|}{$\mathbf{2 0 0 8}$} & \multicolumn{1}{c|}{$\mathbf{2 0 0 9}$} \\
\hline Croatia & 152,0 & 250,0 & 242,0 & 276,0 & 323,0 & 417,0 & 454,0 \\
\hline Slovenia & 20,3 & 18,7 & 18,1 & 22,5 & 27,3 & 32,6 & 27,9 \\
\hline
\end{tabular}

Source: Tourist Institute 2010, Warsaw

Table 6: Polish tourists in Croatia and Slovenia 2003-2009, growth compared to the previous year in \%

\begin{tabular}{|l|r|r|r|r|r|r|r|}
\hline & $2003 / 2002$ & $2004 / 2003$ & $2005 / 2004$ & $2006 / 2005$ & $2007 / 2006$ & $2008 / 2007$ & $2009 / 2008$ \\
\hline Croatia & 91 & 164 & 97 & 114 & 117 & 129 & 109 \\
\hline Slovenia & 82 & 92 & 97 & 124 & 121 & 119 & 86 \\
\hline
\end{tabular}

Source: Tourist Institute 2010, Warsaw

Tables 5 and 6 show an increase in the number of Polish tourists in Croatia and Slovenia between 2003 and 2009. Especially the flow of Polish tourists to Croatia surpasses essentially the average growth of Croatian tourism. But also in Slovenia the increase in the number of Polish tourists exceeded the average growth of tourism more than twice. The accession of Slovenia to the Euro Zone, which may have resulted in a rise of prices for tourism services or was at least perceived so by Polish tourists, had a certain detrimental effect. This may also have been a reason for a shift towards Croatia. Growth rates for 2009 show for the first time an effect of the European economic crisis.

\section{Conclusions}

Based on statistical data it can be stated that Polish tourist flows to Croatia and Slovenia show a dynamic increase in the last two decades. Croatia became one of the main Polish tourist destinations. This is, apart from natural and cultural attractions, mainly due to economic factors, easy accessibility and cultural affinity. Especially 
Croatia corresponds very well to specific demands of the Polish tourist market such as low costs - similar to Egypt, Tunisia or Turkey. This is confirmed by an analysis of changes in tourism volume compared to the economic development in Europe and economic changes in Poland.

The cost factor is certainly an advantage of both Croatia and Slovenia compared to alternative offers in the Adriatic region and its hinterland such as Italy and Austria. Bosnia and Herzegovina as well as Albania are relatively cheaper than Croatia and Slovenia and for their different cultures also attractive for Polish tourists, but lack the security level of Croatia and Slovenia. This makes it very likely that the two will remain major Polish tourist destinations for years to come.

\section{Bibliography}

GUS (ed.) (2000-2010), Rocznik Statystyczny Rzeczypospolitej Polskiej (years 2000-2010) Warszawa.

Tourist InStitute, WARSAW (ed.), http://www.intur.com.pl/wyjazdy_polakow2009.pdf 



\section{ISR-Forschungsberichte}

1 Zoltán CSÉFALVAY und Walter ROHN (1991): Der Weg des ungarischen Arbeitsmarktes in die duale Ökonomie

2 Elisabeth LICHTENBERGER (Hg., 1991): Die Zukunft von Ostmitteleuropa. Vom Plan zum Markt

3 Marlies SCHULZ (1991): Der Tauschwohnungsmarkt in der zentralistischen Planwirtschaft - das Beispiel von Ostberlin

4 Helga SCHMIDT (1991): Die metropolitane Region Leipzig - Erbe der sozialistischen Planwirtschaft und Zukunftschancen

5 Hugo PENZ (1992): Entwicklungsstruktur und Zukunft von ländlicher Siedlung und Landwirtschaft in der ČSFR und in Ungarn

6 Zoltán CSÉFALVAY und Walter ROHN (1992): Die Transition des ungarischen und Budapester Wohnungsmarktes

7 Alina MUZIOŁ-WĘCŁAWOWICZ (unter Mitarbeit v. Josef Kohlbacher, 1992): Die Transformation des Wohnungswesens in Polen - eine Analyse des Warschauer Wohnungsmarktes

8 GrzegorzWECCAWOWICZ (unter Mitarbeit v. JosefKohlbacher, 1993): Die sozialräumliche Struktur Warschaus - Ausgangslage und postkommunistische Umgestaltung

9 Markus SEIDL (1993): Stadtverfall in Bratislava

10 Heinz FASSMANN, Josef KOHLBACHER und Ursula REEGER (1993): „Suche Arbeit““ - Eine empirische Analyse über Stellensuchende aus dem Ausland

11 Heinz FASSMANN, Zoltán CSÉFALVAY und Walter ROHN (1993): Regionalstruktur im Wandel - Das Beispiel Ungarn

12 Ursula BAUER (1994): Europa der Regionen - Zwischen Anspruch und Wirklichkeit

13 Heinz FASSMANN, Josef KOHLBACHER und Ursula REEGER (1995): Die ,neue Zuwanderung" aus Ostmitteleuropa - Eine empirische Analyse am Beispiel der Polen in Österreich

14 Heinz FASSMANN (Hg., 1995): Immobilien-, Wohnungs- und Kapitalmärkte in Ostmitteleuropa. Beiträge zur regionalen Transformationsforschung

15 Heinz FASSMANN und Christiane HINTERMANN (1997): Migrationspotential Ostmitteleuropa. Struktur und Motivation potentieller Migranten aus Polen, der Slowakei, Tschechien und Ungarn

16 Heike JÖNS und Britta KLAGGE (1997): Bankwesen und Regionalstruktur in Ungarn

17 Konrad SCHERF (1998): Die metropolitane Region Berlin. Genese und Niedergang, Revitalisierung und Innovation

18 HeinzFASSMANN, Christiane HINTERMANN, JosefKOHLBACHER und Ursula REEGER (1999): „Arbeitsmarkt Mitteleuropa“. Die Rückkehr historischer Migrationsmuster

19 Zoltán CSÉFALVAY (1999): Die Wettbewerbsfähigkeit der österreichischen Großstädte. Theoretische Ansätze und empirische Befunde

20 Axel BORSDORF und Michaela PAAL (Hg., 2000): Die ,alpine Stadt“ zwischen lokaler Verankerung und globaler Vernetzung. Beiträge zur regionalen Stadtforschung im Alpenraum 
21 Walter ROHN (2000): Forschungseinrichtungen in der Agglomeration Wien. Stellung im Innovationsprozeß und Einbindung in innovative Netzwerke

22 Vera MAYER (2000): Regionale Innovationspotentiale und innovative Netzwerke der Industrieunternehmen in der metropolitanen Region Wien. Ergebnisse einer Unternehmensbefragung

23 Axel BORSDORF (Hg., 2000): Perspectives of Geographical Research on Latin America for the $21^{\text {st }}$ Century

24 Wolfgang BERGER (2001): Photovoltaics in Europe in the Year 2020. Utilities, Sustainable Development and Culture

25 Heinz FASSMANN, Josef KOHLBACHER und Ursula REEGER (in Zusammenarbeit mit Katharina DEMEL und Irene STACHER, 2001): Integration durch berufliche Mobilität? Eine empirische Analyse der beruflichen Mobilität ausländischer Arbeitskräfte in Wien

26 Walter ROHN (2002): Regelung versus Nichtregelung internationaler Kommunikationsbeziehungen. Das Beispiel der UNESCO-Kommunikationspolitik

27 Vera MAYER (2002): Wohnpräferenzen von Jugendlichen in Wien. Ein Beitrag zur Kultur- und Sozialgeographie des Wohnens

28 Michael JANOSCHKA (2002): Wohlstand hinter Mauern. Private Urbanisierungen in Buenos Aires

29 Axel BORSDORF und Christof PARNREITER (Hg., 2003): International Research on Metropolises - Milestones and Frontiers

30 Heinz FASSMANN, Josef KOHLBACHER und Ursula REEGER (2004): Polen in Wien. Entwicklung, Strukturmerkmale und Interaktionsmuster

31 Josef KOHLBACHER und Ursula REEGER (2005): Aus aller Herren Länder? Wien als Studienort und internationale Bildungsmetropole

32 Josef KOHLBACHER und Ursula REEGER (2006): „Gespanntes Nachbarschaftsverhältnis?" Eine empirische Analyse des interethnischen Zusammenlebens in unterschiedlichen Wohnbaukategorien in Wien

33 Josef KOHLBACHER und Ursula REEGER (2006): Die Dynamik ethnischer Wohnviertel in Wien. Eine sozialräumliche Longitudinalanalyse 1981 und 2005

34 Wolfgang BOSSWICK, Heinz FASSMANN, Josef KOHLBACHER and Doris LÜKENKLASSEN (2007): Housing and Residential Segregation of Migrants. A state-of-the-art report

35 Josef KOHLBACHER und Ursula REEGER (2008): Staatsbürgerschaftsbonus beim Wohnen? Eine emprische Analyse der Unterschiede zwischen eingebürgerten und nichteingebürgerten Zuwanderern/-innen hinsichtlich ihrer Wohnsituation in Wien

36 Heinz FASSMANN and Yvonne FRANZ (Hg., 2010): Integration Policies on the Local Level: Housing Policies for Migrants. Examples from New York City, St. Paul, Antwerp, Vienna and Stuttgart

37 Josef KOHLBACHER, Ursula REEGER and Philipp SCHNELL (2012): Neighbourhood Embeddedness and Social Coexistence. Immigrants and Natives in Three Urban Settings in Vienna 